corresponding increase in the rates of chronic disease. How can elderly people be cared for adequately without greatly increasing the resources available? Minimally invasive surgery is one of the most important technological changes to allow reduction of the rates of hospitalisation. From an economic point of view this is desirable because each procedure becomes cheaper, mainly due to a shorter hospital stay and an earlier return to normal activities. ${ }^{1}$ Expenditures in health insurance and social insurance are also reduced. If hospital beds are not closed, however, many of the benefits of shorter lengths of stay will not be realised.

A potentially negative consequence of the new technologies is that they allow operations to be performed in circumstances where previously nothing would have been done. Kidney stones were not previously treated unless they were symptomatic, but, with extracorporeal shockwave lithotripsy replacing open surgery, it is now routine to treat any stone that happens to be found during investigations for other purposes. ${ }^{22}$ Gall bladders were not removed unless gall stones were associated with infection. Now stones can be easily removed, and why not take the gall bladder at the same time? Women with pelvic pain often have a diagnostic laparoscopy, and gynaecologists have now started to remove normal appendixes during these diagnostic procedures. ${ }^{23}$ Such practices threaten to increase overall costs of care with no measurable benefit and some risk to patients.

1 Banta HD. The budget is blind: the case of minimally invasive therapy in Europe. Leiden: TNO, 1991. (Presented to the FAST Programme, EC, Brussels.) 2 Banta HD. Diffusion of minimally invasive therapy in Europe. Minimally Invasive Therapy 1992;1:189-95.
3 Dubois F, Icard P, Berthelot G, Levard H. Coelioscopic cholecystectomy, preliminary report of 36 cases. Ann Surg 1990;211:60-2.

preilin $T$, Talamin Surg Clin North Am 1990;70:1249-62.

5 Diagnostic and therapeutic technology assessment (DATTA): laparoscopic cholecystectomy. IAMA 1991;265:1585-7.

6 Southern Surgeon's Club. A prospective analysis of 1518 laparoscopic cholecystectomies. N Engl f Med 1991;302:30-1.

7 Reddick E, Olsen D. Outpatient laparoscopic laser cholecystectomy. Am f Surg 1990;160:485-7.

8 Holahan T. Laparoscopic cholecystectomy. Lancet 1991;338:801-3.

9 Vondeling $\mathrm{H}$, Haerkens E, De Wit A, Bos M, Banta HD. Diffusion of minimally invasive therapy in the Netherlands. Health Policy 1993;23: 67-81.

10 Tavmergen E, Mecke H, Serum K. Pelviscopic ovarian surgery, possibilities and borderlines. Zentralbl Gynakol 1990;112:1405-11.

11 Goodman M, Johns D, Levine R, Reich H, Levinson C, Murphy A, et al. Report of the study group: advanced operative laparoscopy. Foumal of Report of the study group: advace
Gynecologic Surgery 1989;5:353-60.

12 Cook A, Rock J. The role of laparoscopy in the treatment of endometriosis. Fertil Steril 1991;55:663-80.

13 Hamberg P, Gillquist J, Lysholm J. A comparison between arthroscopic meniscectomy and modified open meniscectomy: a prospective randomized study with emphasis on post-operative rehabilitation. I Bone foint Surg (Br) 1984;66:189-92.

14 Peckham M. Research and development in the National Health Service. Lancet 1991;338:367-71.

15 Advisory Group on Health Technology Assessment. Assessing the effects of health technologies, principles, practice, proposals. London: Department of Health, 1992.

16 Burn J. A blueprint for day surgery. Anaesthesia 1979;34:790-805.

17 College voor ziekenhuisvoorzieningen. Advies inzake dagverpleging in algemene ziekenhuizen. Utrecht: the College, 1987.

18 ECRI. Outpatient surgery: its perils and prospects. Health Technology 1987;1:91-8.

19 Society of American Gastrointestinal Endoscopic Surgeons. The role of laparoscopic cholecystectomy: guidelines for clinical application. Los Angeles, California: the Society, 1990

20 Bergstrom R, Hamberg P, Lysholm J, Gillquist J. Comparison of open and endoscopic meniscectomy. Clin Orthop 1984;184:133-6.

21 Northmore-Ball M, Dandy D. Long-term results of arthroscopic partial meniscectomy. Clin Orthop 1982;167:34-42.

22 Vrolijk H, Straten G. Het einde van het stenen tijdperk? Appeldoorn, the Netherlands: Studiecentrum voor Technologie en Beleid TNO, 1988.

23 Whitworth C, Whitworth P, Sanfillipo J, Polk H. Value of diagnostic laparoscopy in young women with possible appendicitis. Surg Gynecol Obstet $1988 ; 167: 187-90$.

\title{
Senior house officers: the lost tribes
}

\author{
Luisa Dillner
}

There are more senior house officers than doctors in any other training grade in Britain but nobody knows what they do in hospitals or has a clear idea what skills they should be learning. Nobody is responsible for them and they suffer from having a poor career structure and inadequate training. Now that there are government initiatives to reduce the hours that junior doctors work and to limit the time it takes to train to become a specialist, the problems that senior house officers face can no longer be ignored. A conference for senior house officers held last week talked about the problems that they face and tried to find some solutions.

The new deal on junior doctors' hours has uncovered the biggest mystery in medical staffing. As soon as regional task forces tried to reduce junior doctors' hours they found that no one knew how many senior house officers there were or what they were doing. No one, it seems, is responsible for their training, career structure, or working conditions. While the General Medical Council keeps an eye on undergraduates and the royal colleges watch over doctors in higher specialist training, senior house officers have no one to speak for them.

Last week the voice of senior house officers was heard at a national conference to discuss the problems they face and the possible solutions. Organised jointly by the BMA, $B M F$, and Oxford Regional Health Authority, the conference attracted over 300 people, nearly two thirds of whom were senior house officers.

\section{What are the problems?}

One of the reasons why senior house officers are neglected is that they are a migrant work force. The title of the conference, "SHOs: The Lost Tribes," accurately describes their predicament, said Elisabeth Paice, associate postgraduate dean at North East Thames regional health authority. "There are more senior house officers than any other training grades but they are constantly on the move. When you are in a post for only six months, even if you think something should be changed it is difficult to get the energy to do something about it," she said. "If you do try to do something about it, the hospital authorities or the consultants think that you will be moving on and they might as well wait for someone less troublesome to replace you. One senior house officer said to me that the only thing she had managed to change were her references."

Elisabeth Paice has visited 16 hospitals in her region and talked to 303 senior house officers about their jobs. She asked about their workload, level of supervision, education, and living conditions. "Many worked jolly hard and liked it that way but 152 whom I spoke to said that their workload was heavy or excessive. Some of them found that they were seriously stressed and talked about having six months off or abandoning medicine altogether," she told the conference. "It wasn't simply the hours of work. In some places I visited the new deal was coming in and the reductions in hours were apparent, but in some areas the same body of work was being done by the same number of
British Medical Journal London WC1H 9JR

$B M \mp$ 1993;307:1549-5 

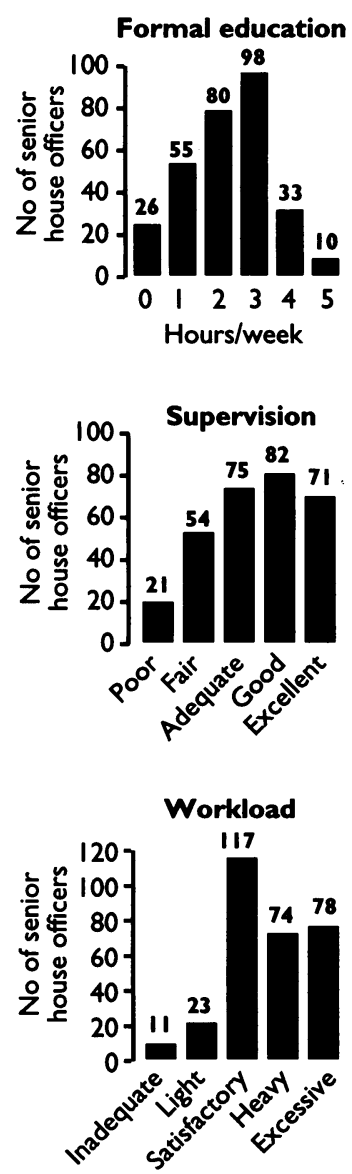

North East Thames survey of senior house officers people in shorter hours. This was leading to an increased intensity of work but decreased contact with colleagues and consultants."

Many of the senior house officers who felt stressed worked in accident and emergency departments. One told Dr Paice that when he worked a 12 hour shift he did not get time to sit down, and when he went to buy a sandwich he would be accosted by people who were angry at how long their relatives were waiting to be seen.

It was not always the busiest posts that produced the most stress. "Senior house officers could cope with intolerable working conditions so long as they were well supported by their consultants," said Dr Paice.

\section{Poor supervision}

Supervision was, however, often inadequate when senior house officers started in specialties that they had experienced only as medical students. Induction seemed to be one of the biggest problems. One senior house officer in paediatrics was shown how to resuscitate a neonatal dummy and then told that she was on call for distressed babies on the labour ward. "You need more introduction to a specialty than that."

Dr Paice found that a quarter of senior house officers had carried out procedures that they did not feel competent to do and felt that they had put their patients at risk. Educational programmes were patchy, with under half the senior house officers getting three hours' teaching a week.

About a quarter of the senior house officers had not been given any feedback from consultants on how they were doing, making it difficult for them to know if they were suited to a specialty. When feedback was given, it was often given inappropriately. One senior house officer said that he had been confronted by four consultants who went through all the things he had done wrong in the past four months.

So if the workload, supervision, and education of senior house officers were so bad, what were the living conditions like? Some senior house officers had rooms without locks, some had rooms with cockroaches, and others had to walk across an unlit car park where a stabbing and rape had taken place. Even food was scarce. "Some hospitals provide no food after lunch," said Dr Paice. "One senior house officer said that when she was on call over Christmas she was given a bag of sandwiches and an apple."

\section{Keeping the NHS afloat}

Although the NHS treats senior house officers badly, hospitals could not survive without them, said Dr Donal Duffin, a junior hospital doctor from Belfast. Even the minister for health, Dr Brian Mawhinney, acknowledged this when he launched the conference.

Senior house officers deliver most of the direct care to patients. "There is a conflict between service and training," said Dr Duffin. "Senior house officers should be able to have their training supervised by consultants instead of learning by the process of see one, do one, teach one. Errors are rare, but they occur when juniors are asked to do a procedure when there is nobody else to do it and they know that their consultant will not take kindly to being asked to come in."

The system of changing specialties without proper induction courses was "lunacy," Dr Duffin argued. "On 31 July you can be a senior house officer in care of the elderly and on 1 August you can be on a neonatal unit. On my first day as a senior house officer on the coronary care unit in the largest teaching hospital in Belfast I was handed the arrest bleep at 915 am. At 920 am I was bleeped to the intensive care unit by a consultant anaesthetist because he was having problems."

\section{Adequate support}

When senior house officers continually feel tired and unsupported they become cynical, said Phil Hammond, a part time lecturer in communication skills at Birmingham University and Private Eye's medical correspondent. "My first job as a senior house officer was on a special care baby unit. I would get so tired that when babies died I would feel curiously unaffected by it. Sometimes I would cry but often I would go to bed feeling quite relieved."

Dr Hammond said that it was easy for doctors to be more supportive of each other-simply to offer to hold a colleague's bleep when he or she was tired. It was also easy to praise people rather than teach them by humiliation. Medical students are delighted when they got a compliment. "You can work in the NHS for 40 years and never get a compliment."

In the discussion after the first three speakers, senior house officers provided experience of their own problems. One said that it was impossible to pass postgraduate exams while working full time. "I've been a senior house officer for five years," she said, "I need some careers advice." Another said that she had been off work for four months and was taking antidepressants after doing a particularly stressful job. "I didn't know who to turn to," she said. "My consultant was not easy to talk to and I was quite ill before I heard of House Concern, a psychotherapy service for junior doctors in Newcastle."

An associate dean from London said that she thought some posts-in neonatal medicine, for example -were unsuitable for senior house officers. At least one senior house officer did not agree. "Technical jobs aren't inappropriate for us-it's just that we are not trained to do them."

The conference was unanimous that training was inadequate. Janet Grant, professor of medical education in London, said that even trainees in general practice did not get to their half day vocational training courses. "Only about one third of them get to more than $75 \%$ of the meetings and $10 \%$ attend none of the meetings at all," said Professor Grant.

\section{Careers choice}

Isobel Allen, who has studied doctors' views on careers, was convinced that careers counselling for senior house officers was as inadequate as training. "Juniors complain that the career structure is increasingly rigid, that they cannot deviate into interesting side lines," she said. "Employers expect them to reach a certain grade by a certain age, and this disadvantages women and doctors who have changed career. Career advice is patchy, and doctors make careers choices based on negative decisions-they decide what they don't want to do. Careers advice is not good in medical schools."

Ms Allen warned that seeking careers advice could be dangerous - senior house officers told her that if they asked for help it looked as though they were unsure of what they wanted to do. "Senior house officers are concerned that if they look less than single minded it will be the kiss of death to their careers."

It was, however, best not to advertise your single mindedness if it was directed towards general practice, said Ian Banks, chairman of the general practice trainees subcommittee. "If you admit to being a trainee in general practice you'll get no study leave and end up holding a retractor for the rest of your life," he said. Although the Royal College of General Practitioners has minimum criteria for training in senior house 
officer grades, hospital training is still of poor quality and inappropriate, said Dr Banks.

The crux of the problem may be that no one knows what senior house officer posts are for. "Are they for doctors to develop generic skills-the sort of skills that doctors need whatever specialty they enter?" asked John Hasler, regional postgraduate advisor in general practice in Oxford. "Should they be gaining communication skills, auditing skills, and general clinical experience? Or are senior house officers simply there to run the hospital at night? The problems of juniors are the same whether they are in hospital medicine or planning to become general practitioners. They have poor accommodation, too much work, and a lack of planned education."

It is not surprising that some senior house officers find it difficult to cope. When they do need help they may not know where to go. Robert Hale, a psychotherapist at the Tavistock Clinic, told the conference that clinical tutors often felt unable to deal with the emotions of junior staff. "Senior house officers are the largest proportion of doctors who refer themselves to the clinic," he said. "Problems tend to become apparent in senior house officers because it's the first time that they have to take responsibility."

\section{What are the solutions?}

Who then will take responsibility for senior house officers? Several speakers thought that the Calman report on specialist training would bring senior house officers into the centre of the stage. This report, from a working party chaired by Kenneth Calman, the chief medical officer, was produced in response to criticism from the European Commission on the way that Britain trained its specialists. Its recommendations include combining registrar and senior registrar grades and reducing the length of training programmes.

Donal Duffin warned of a potential gap between senior house officers and the new, unified higher training grade. If staff predictions are not accurate and the competition for posts in specialist training becomes excessive, doctors could remain stuck at senior house officer level for four or five years, he said.

Barbara Clayton, chair of the Standing Committee on Postgraduate Medical Education, suggested that postgraduate deans should be in charge-they held $50 \%$ of the budget for junior doctors' training and could insist on better training. "Medical colleges and postgraduate deans must get some agreement on a generic curriculum for senior house officers. But the curriculum should allow people who feel that they are in the wrong career to be able to switch. Other speakers felt

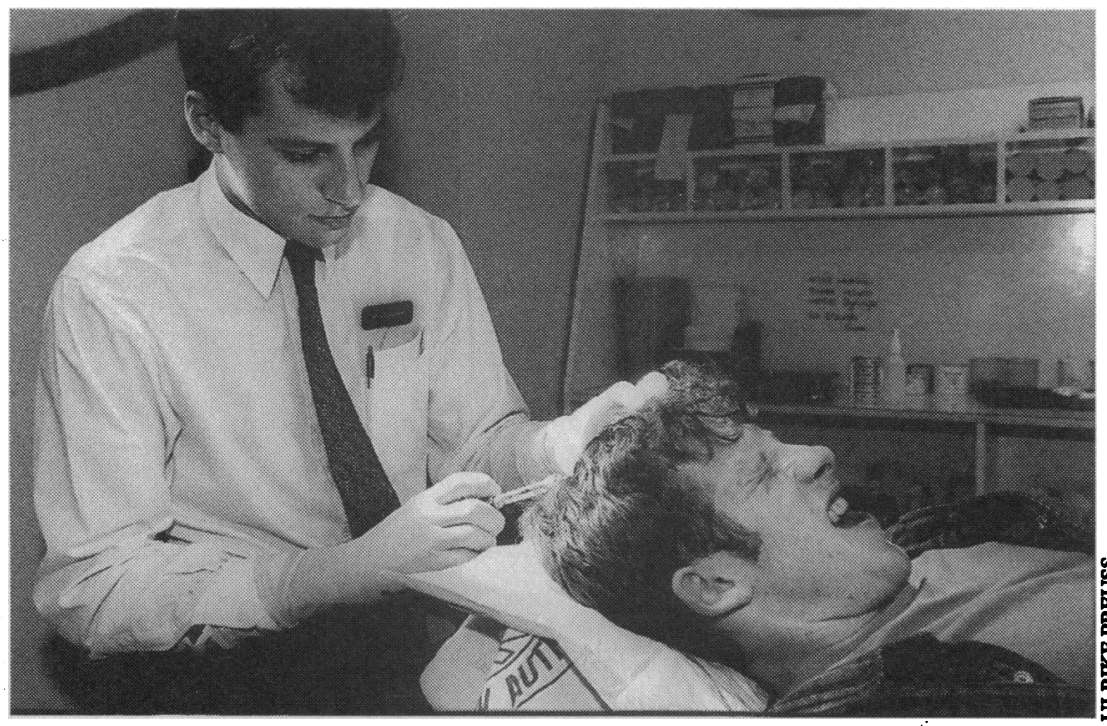

Senior house officers' training and conditions of service need emergency attention that postgraduate deans are not the best people for the job.

Senior house officers at the conference were by no means unanimous in what sort of skills they wanted. Roughly half wanted a broad, general education that would provide useful experience for any specialtyothers wanted to specialise as soon as possible and link posts to the single higher training grade.

\section{Consultants must provide more of the care}

Chris Bulstrode, an orthopaedic surgeon from Oxford, argued that the race to become more and more specialised does nothing for the hospital service. Already, he said, senior house officers in psychiatry were horrified at being asked to cross cover other parts of the hospital because they considered themselves to be already in specialty training schemes.

To provide the best deal for patients the health services had to become consultant based; this would also help to bring down the hours that juniors worked and offer more supervised training. "When consultants start providing the service patients get discharged from outpatients and the emergency operating list is finished before midnight; for medical admissions at least, a third of admissions can be avoided if a consultant reviews the patients on call," said Dr Bulstrode.

The relationship with consultants was one of the most important factors in determining how well senior house officers coped. Robert Hale said that they wanted someone who was benign, firm, and fair, who would provide an apprenticeship.

Peter Bloomfield, a cardiologist from Edinburgh, emphasised how the needs of consultants and senior house officers overlap. Consultants wanted to teach senior house officers enough for them to help with the service commitment and wanted to receive some information about other specialties that senior house officers passed through on their rotations.

\section{The way forward}

At the beginning of the conference Muir Gray, director of health policy and public health at Oxford regional health authority, asked delegates for radical suggestions for change. We can achieve the targets in the new deal, he said, but we need to transform working practices. The favourite suggestions from delegates were putting consultants on call and charging higher rates of pay for senior house officers' overtime.

Dr Gray asked whether the senior house officer grade should be made redundant. "It's so full of illogicalities that it may not be sustainable," he said. He asked for the Department of Health, the royal colleges, the deans, and the regions to nominate people to look after senior house officers for 1994. The BMA's Junior Doctors Committee should concentrate on senior house officers, he said.

The most striking thing about the conference was not the solutions that it came up with but the fact that it gave senior house officers an opportunity to say how they felt. It also gave them the chance to hear about examples of good practice. One senior house officer from Ipswich said that she was on a good rota and had met her educational supervisor twice and found him willing to talk about emotional problems. She had protected study time and met with managers, senior nurses, and the clinical director at a monthly forum to discuss how working conditions could be made better. "I enjoy my job and I don't feel tired," she said. "It's distressing to hear how so many senior house officers are unhappy." The conference was, however, delighted to hear that progress could be made. Ipswich can be recreated elsewhere, said Dr Gray. It is not an impossible task. 